\title{
On comfort and the culture of cultural geography
}

Article

Accepted Version

Geoghegan, H. (2016) On comfort and the culture of cultural geography. Area, 48 (3). pp. 378-383. ISSN 1475-4762 doi: https://doi.org/10.1111/area.12290 Available at https://centaur.reading.ac.uk/66763/

It is advisable to refer to the publisher's version if you intend to cite from the work. See Guidance on citing.

To link to this article DOI: http://dx.doi.org/10.1111/area.12290

Publisher: Royal Geographical Society

All outputs in CentAUR are protected by Intellectual Property Rights law, including copyright law. Copyright and IPR is retained by the creators or other copyright holders. Terms and conditions for use of this material are defined in the End User Agreement.

\section{www.reading.ac.uk/centaur}

\section{CentAUR}

Central Archive at the University of Reading

Reading's research outputs online 
For Classics revisited: New Directions in Cultural Geography (1987) by Denis Cosgrove and Peter Jackson

\begin{abstract}
In this commentary, the author revisits Cosgrove and Jackson's article in two parts: first, outlining the personal significance of Cosgrove and Jackson's agenda by revisiting her roots in, and route through, cultural geography over the last two decades; and second, reengaging with the paper's key themes and arguments in a contemporary context, considering its on-going influence, with reference to work on methodological innovation, collaborations with other practitioners and transdisciplinarity. The author concludes by calling for a continued practice of revisiting within cultural geography to help ourselves and our students understand where cultural geographies come from and may be going next.
\end{abstract}

\title{
Key Words
}

Cultural geography, transdisciplinarity, landscape, enthusiasm

\section{Contact Details}

Dr Hilary Geoghegan

Department of Geography \& Environmental Science

University of Reading

Whiteknights

Reading

RG6 6AB

h.geoghegan@,reading.ac.uk 


\section{Commentary}

Denis Cosgrove and Peter Jackson’s 1987 paper ‘New Directions in Cultural Geography' outlined the sort of cultural geography - involving an attention to landscape and everyday life and the adoption of ethnographic approaches - that I studied and was inspired by at university a decade later. Revisiting this paper, almost thirty years after its publication, I immediately feel at home with its focus and core mission for cultural geography post-1987. There is a comfort in the theoretical and empirical directions proposed by the authors, such as the relations between 'elite' and 'popular' cultures, the representation of real and imagined 'landscapes', the place of 'civil society', and the geographies of 'consumption'. These themes opened up spaces for the subjects and specialisms that we now take for granted when describing the features of contemporary cultural geography, for example mobilities, consumption geographies, geographies of architecture, postcolonialism, children and youth, hybrid geographies, nonrepresentational theory, to name but a few (ESRC 2013). The authors also indicated a more 'interpretative' discipline, encouraging cultural geographers to seek out new research methods. My short commentary is in two parts: first, I outline the personal significance of Cosgrove and Jackson's agenda by revisiting my roots in, and routes through, cultural geography over the last two decades; and second, I re-engage with the paper's key themes and arguments in a contemporary context, considering its on-going influence, with reference to work on methodological innovation, collaborations with other practitioners and transdisciplinarity.

As cultural geographers we are taught early on in our careers to be attentive to where, how and by whom knowledge is made. I am a white British woman writing here about a largely British cultural geography - and this is important to acknowledge - a point I return to in my conclusion. My fascination began shortly after I finished my A-levels at an all-girls comprehensive school in South East England. In 2000, I was a second year undergraduate at the University of Exeter, being taught by Catherine Leyshon (nee Brace) (Brace 1999a, 1999b), a former student of Denis Cosgrove, who was interested in landscape as 'a particular way of composing, structuring and giving meaning to an external world' and 'the symbolic qualities of landscape, those which produce and sustain social meaning' (Cosgrove and Jackson 1987, 96 original emphasis). Kate's module entitled 'Landscape and Representation' was my first encounter with cultural geography specifically through the landscapes of Capability Brown and Gainsborough's painting $\mathrm{Mr}$ and Mrs Andrews. Where else, other than in cultural geography, would an undergraduate assessment involve a brief from an $18^{\text {th }}$ century Lord and Lady of the Manor in want of a new garden. This creative writing opportunity to combine theoretical ideas about landscape with historically grounded research, inspired me to apply for the Masters in Cultural Geography (Research) at Royal Holloway, University of London. During my MA, my cohort and I enjoyed a half-day fieldclass walking the memorial landscapes of Runnymede with Denis Cosgrove himself. The names and works of Cosgrove and Jackson loomed large in my induction into cultural geography. The first academic books I read cover-to-cover were The Iconography of Landscape (Cosgrove and Daniels 1988) and Maps of Meaning (Jackson 1989). Alongside Mike Crang's Cultural Geography (1998) and Don Mitchell's An Introduction to Cultural Geography (2000), the breadth of topics discussed in these works inspired my dissertations on landscape, memory and popular culture.

I embarked on my PhD at Royal Holloway in the wake of the 'cultural turn' and the renewal of material culture studies, as illustrated by Cosgrove and Jackson in their discussion of the cultural materialism of Raymond Williams and the need to understand 
how 'people transform the mundane phenomena of the material world into a world of significant symbols to which they give meaning and attach value' (1987, 99). Mixing social and cultural geography, I focussed on the emotional and material cultures of 'enthusiasm' and used the work of the CCCS to study one particular subculture surrounding technology. I explored how some male, retired members of the 'so-called consumption classes' (Cosgrove and Jackson 1987, 99) are attached to and socialise around obsolete technologies, combining documentary evidence with ethnographic encounters and interviews (Geoghegan 2009; 2013). As I mentioned above, an academic's research interests are in part shaped by those scholars we encounter and the institutions we pass through. It strikes me now by revisiting this article that the expertise of my supervisory team of Felix Driver (1988; 2001) and Phil Crang (1992; 1994) reflected many of the concerns of the new directions in cultural geography advocated by Cosgrove and Jackson: 'contemporary as well as historical (but always contextual and theoretically informed); social as well as spatial (but not confined exclusively to narrowlydefined landscape issues); urban as well as rural; and interested in the contingent nature of culture, in dominant ideologies and in forms of resistance to them' $(1987,95)$. The importance of 'culture' to my research interests and approach to being a geographer was cemented yet further by my participation in 'Landscape Surgery', a fortnightly social and cultural geography research group meeting established by Denis Cosgrove during his time as a Professor at Royal Holloway. As a doctoral student, Landscape Surgery provided my peers and I with a safe space to share and debate ideas and enjoy the company of cultural geographers (Martins 2009).

Towards the end of my $\mathrm{PhD}$, and 20 years after Cosgrove and Jackson's article was published, Tara Woodyer $(2008,2012)$ and I began to think about the enchantment of material things, extending our ideas about objects and their attendant meanings and values. We were interested in affect, emotion and vital materialism (Bennett 2001). Over a post-seminar beer, we decided to convene two sessions at the 2007 RGS-IBG Annual Conference on 'Enchanting Geographies'. Little did either of us imagine that this would lead us to a paper in Progress in Human Geography where we would define enchantment as 'an open, ready-to-be- surprised 'disposition' before, in, with the world', launching our cultural geography 'manifesto' for 'a less repressed, more cheerful way of engaging with the geographies of the world' (Woodyer and Geoghegan 2013, 196; Geoghegan and Woodyer 2014). A paper that has gone on to offer a bridge between human and physical geography (see Progress in Physical Geography (Brierley et al. (2013)). The culture of cultural geography has, in my experience, always been supportive of new theoretical and empirical directions regardless of the career stage or geographical location of the geographer. Early-career geographers must continue to be encouraged to host workshops, symposia and conference sessions to enable open debate - much like the Social Geography Study Group conference at University College London upon which Cosgrove and Jackson's paper is based.

Now, I'm a lecturer and I teach first year undergraduates about the history and philosophy of geography. We cover the twists and turns of the emergence of human geography and its interest in 'theoretical problems' (Cosgrove and Jackson 1987, 95) and understanding of culture as 'politically contested' (Cosgrove and Jackson 1987, 99) and 'time- and space-specific' (Cosgrove and Jackson 1987, 99). Students learn about place and space through the work of Carl Sauer, the Berkeley School, Yi-Fu Tuan, Doreen Massey and Tim Cresswell. These first year geographers prefer real-world examples and are initially more comfortable with Sauer's ideas about landscape and differing barn types in North America and Christaller's Central Place Theory. However as we move towards, 
what Cosgrove and Jackson described as, a cultural geography 'where particular cultural forms can be related to specific material circumstances in particular localities 'on the ground" (1987, 99), I see a shift in their appreciation of (cultural) geography and what our approach allows us to do and say about the world. Cultural geography enables the spatial exploration of activities, processes and identities in the world around us and I regale them with contemporary geographies of architecture (Kraftl and Adey 2008; Kraftl 2010), big things (Jacobs 2006), materials things (Jackson 2000), creativity (Hawkins 2013a), and mobilities (Cresswell and Merriman 2011). Recounting the personal significance of these new directions in cultural geography might seem rather selfindulgent, however it serves to emphasise here the article's enduring legacy in both research and teaching.

I now come to the second half of my short commentary and a focus on the paper's ongoing influence. At the moment, cultural geography is the subject that other disciplines want to be (Amin 2009). Over the last thirty years, cultural geographers have built on those early interests in landscape (Lorimer 2005) and theoretical problems (Thrift 2005) and learnt to speak many disciplinary languages. They've travelled across disciplinary borders and thrive on the intellectual challenge of 'space [not] being this flat surface ... [but] a pincushion of a million stories' (Massey 2013, unpaginated). For me, the legacy of the cultural geography reported on by Cosgrove and Jackson in 1987 lies in three key areas, namely our capacity for and comfortableness with methodological innovation, collaborations with other practitioners and transdiciplinarity.

First, methodology has always been a site of innovation for cultural geographers, from the attention to ethnography, thick description and the importance of language in the late 1980s (Crang 2002) to the focus on things (Cook 2004) to the use of photography, video and participatory methods (Spinney 2011, Woodyer 2008, Butler 2007; Garrett 2011; Mills 2013) to the collaborations with artists, curators, performers and scientists (Nash et al. 2002). Cosgrove and Jackson indicated 'a broadening of the sources available for study in cultural geography', suggesting 'landscapes may be studied across a variety of media and surfaces: in paint on canvas, writing on paper, images on film as well as in earth, stone, water and vegetation on the ground' (Daniels and Cosgrove 1987)' (1987, 96). The work of my peers is testament to the legacy of this suggestion, for example - Harriet Hawkins's work at the interface of geography and art (2013b), Justin Spinney's combination of cycling and non-representational theory (2006), Amanda Rogers's interdisciplinary journey through cultural geography and the performing arts (2012), and Tara Woodyer's work on embodied practices of play (2012). Their acts of methodological bravery have now become popular approaches to creativity, mobility and performance - extending yet further the ways in which cultural geographers are able to understand what it means to be human. Cultural geography's attention to methodology and, as I outline in the next section, openness to collaboration has also created space for hidden, inspirational, and transgressive stories to emerge, in the company of the public, volunteers, curators, specialists, experts and children (DeLyser 2014; Driver 2013; Garrett 2014). In addition, cultural geography has also become more public, improving our ability to communicate our work across a range of media and to a diversity of audiences.

Second, and linked, is the collaborative reach of the cultural geographer. I've mentioned above some of the individuals and institutions we have the privilege of working with. This ability to work with other practitioners is important for two reasons. First, in a discussion of the 'cultural geographies of the future' (Wylie 2010), questions were raised 
(and rightly so) regarding the identity of the cultural geographer and the potential impact of our work. Yet it is in collaboration and working across disciplinary borders, through non-academic partnerships, and working with artists, museums, science, public bodies and institutions - specifically our public cultural geographies - that we have a lasting impact. Our collaborations with creative practitioners are second to none - with exciting exchanges between cultural geographers and artists in residence (DeSilvey 2007; Foster and Lorimer 2007; Scalway 2006). Second, if we link this to recent work on public geographies (Fuller 2008, Philo et al. 2015), participatory historical geography (DeLyser 2014), collaborative geographies (Craggs et al. 2013), civic geographies of enthusiasm (Craggs et al. 2015) and museum geography (Geoghegan 2010) - any suggestion that we may lack impact or have a tendency for theoretical hyperbole - can be readily assuaged. Having worked hard to develop these collaborations, I argue, we now need to focus some of our attention on popularising our 'cultural geography' as a subject of interest beyond non-academic collaborators and towards the public.

Third, cultural geography is uniquely positioned to lead and contribute to transdisciplinary research involving the humanities, social sciences and natural sciences (Castree et al. 2014). Present-day attempts to make sense of and respond to global issues, such as climate change, (bio)security and plant health, require the involvement of cultural geographers and their willingness to transcend disciplinary norms. Cosgrove and Jackson identified a 'form of 'green' cultural geography', examining 'themes of human agency with respect to the natural environment and its ecological balances' $(1987,96)$. Extending beyond the landscape as a key site for research on the environment, ideas of the morethan-human, non-human/human relations, and the new epoch of the Anthropocene reveal some of the exciting ways in which social and cultural geographers are leading on examining the complex inter-relationships or 'nexuses' between people and nature (Head and Atchison 2009; Ginn 2014; Brace and Geoghegan 2011). In the UK, cultural geographers have played key roles in a number of RCUK-funded interdisciplinary initiatives including: Rural Economy and Land Use Programme (RELU), Living With Environmental Change (LWEC) and Landscape and Environment Programme (Whatmore 2009; Potter et al. 2011; Daniels and Veale 2014). Their leadership and involvement in such schemes is testament to Cosgrove and Jackson's observation that 'Culture is not a residual category, the surface variation left unaccounted for by more powerful economic analyses; it is the very medium through which social change is experienced, contested and constituted' $(1987,95)$. My own career has been built on this fascination with people and the ways in which individuals and collectives hold contested, contradictory and competing perspectives. I'm about to start work on a project with 35 natural scientists to examine the causes and potential solutions surrounding tree health and Acute Oak Decline in particular. Cultural geography has taught me that people do not experience the world in neat spatial models. Indeed, encounters between people and the material world are messy (Bastian 2013). I will be bringing this expertise to our new project and asking whether living with Acute Oak Decline is preferable to any potential technological or biological solution. I'm proud that cultural geographers have not been afraid to reach across disciplinary boundaries in order to develop theories that allow us to grapple with this interconnected, chaotic and uneven world.

In conclusion, the new directions described in Cosgrove and Jackson's article shaped the cultural geography I have come to know and love. Revisiting their work and that of others during the course of preparing this commentary has certainly revitalised and renewed my commitment to cultural geography. A final point I want to make in relation to Cosgrove and Jackson's paper hones in on the plurality of cultural geographies. For 
Cosgrove and Jackson, 'A unitary view of Culture gives way to a plurality of cultures, each of which is time- and place-specific' (1987, 99 original emphasis). For me, this plurality must be extended in this second decade of the 2000 s to incorporate gender and minority underrepresentation and a commitment to intellectual plurality. Jackson and Cosgrove's reference list contains over 60 texts, only five solely- or co-authored by female scholars: Jacquie Burgess (Burgess and Gold 1985), Dorothy Hobson (Hall et al. 1980), Susan J. Smith (Jackson and Smith 1984) and Doreen Massey (1984) and Catherine Silk (Silk and Silk 1985). Whilst this was reflective of cultural geography at the time, change here has been slow (Crang 2003). Recent research by Maddrell et al. (2016) revealed that there has been a growth in the number of female staff in geography in UK Higher Education establishments, for example an increase between 1978 and 2012/13 from 4\% to 21\% in female professors, $8 \%$ to $48 \%$ in lecturers and researchers, and $31 \%$ to $50 \%$ in female $\mathrm{PhD}$ students (full-time), but women remain under-represented at all career stages beyond postgraduate level. The recent International Benchmarking Review of UK Human Geography (ESRC 2013) acknowledged the unacceptability of minority underrepresentation in geography. One approach to tackling the 'gender problem' is, I argue, to continue the practice of revisiting, by identifying what Whatmore (2006) has described as disciplinary 'returns', and profiling the longevity of women's geographical work through activities such as the 100+ celebration at the 2013 RGS-IBG Annual Conference, marking the centenary of the permanent admission of women to the RGS. I'm updating my first year reading list next term, and I will be including Cosgrove and Jackson's paper, but also those of social and cultural geographers who inspired my own cultural geography and way of being in the discipline (Anderson 1995; Blunt and Rose 1994; Bondi 2014; Bowlby 1984; Brickell 2012; Callard 2003; Crewe and Gregson 1998; Davies 2000; DeLyser 1999; Domosh 1991; Endfield and Morris 2012; Kobayashi 1994; Kong 2001; Little 2002; Morin 1998; Nash 1996; Shurmer-Smith 1998; Till 2005; ToliaKelly 2007; Valentine 1993 - as well as others cited throughout this paper). In so doing, we can continue to ensure that our students and colleagues recognise where the exciting cultural geographies - of the everyday, experiential and material aspects of life, the associated attachments, emotions, performances, politics, and the relations between humans and non-humans - come from and may be going next.

\section{References}

Amin A 2009 Cultural Geography in Gregory D, Johnston R J, Pratt G, Watts M W and Whatmore $\mathbf{S}$ eds The Dictionary of Human Geography Wiley-Blackwell, Oxford 129

Anderson K 1995 Culture and nature at the Adelaide Zoo: at the frontiers of 'human' geography Transactions of the Institute of British Geographers 20 275-294

Bastian M 2013 Why more than human participatory research? (http://www.michellebastian.net/home/why-more-than-human-participatory-research) Accessed 1 May 2016

Bennett J 2001 The Enchantment of Modern Life: Attachments, Crossings, and Etbics Princeton University Press, Princeton, NJ

Blunt A and Rose G eds 1994 Writing Women and Space: Colonial and Postcolonial Geographies Guilford Press, Guildford 
Bondi L 2014 Feeling insecure: a personal account in a psychoanalytic voice Social \& Cultural Geography 15 332-350

Bowlby S R 1984 Planning for women to shop in postwar Britain Environment and Planning D: Society and Space 2 179-199

Brace C 1999a Finding England everywhere: regional identity and the construction of national identity, 1890-1940 cultural geographies 6 90-109

Brace C 1999b Looking back: the Cotswolds and English national identity, c. 1890-1950 Journal of Historical Geography 25 502-516

Brace C and Geoghegan H 2011 Human geographies of climate change: landscape, temporality, and lay knowledges Progress in Human Geography 35 284-302

Brickell K 2012 'Mapping' and 'doing' geographies of home Progress in Human Geography $36225-244$

Brierley G, Fryirs K, Cullum C, Tadaki M, Huang H Q and Blue B 2013 Reading the landscape: integrating the theory and practice of geomorphology to develop placebased understandings of river systems Progress in Physical Geography 37 601-621

Burgess J A and Gold J R eds 1985 Geography, the Media and Popular Culture Croom Helm, London

Butler T 2007 Memoryscape: How audio walks can deepen our sense of place by integrating art, oral history and cultural geography Geography Compass 1 360-372

Callard F 2003 The taming of psychoanalysis in geography Social \& Cultural Geography 4 295-312

Castree N, Adams W M, Barry J, Brockington D, Büscher B, Corbera E, Demeritt D, Duffy R, Felt U, Neves K and Newell P 2014 Changing the intellectual climate Nature climate change 4 763-768

Cook I 2004 Follow the thing: Papaya Antipode 36 642-664

Cosgrove D and Daniels S 1988. The Iconography of Landscape Cambridge University Press, Cambridge

Cosgrove D and Jackson P 1987 New directions in cultural geography Area 19 95-101

Craggs R, Geoghegan H and Keighren I M eds 2013 Collaborative Geographies: The Politics, Practicalities, and Promise of Working Together Royal Geographical Society, London

Craggs R, Geoghegan $\mathbf{H}$ and Neate $\mathbf{H} 2015$ Civic geographies of architectural enthusiasm ACME: An International E-Journal for Critical Geographies 14 367-376

Crang M 1998 Cultural Geography Routledge, London 
Crang M 2002 Qualitative methods: the new orthodoxy? Progress in Human Geography 26 647-655

Crang M 2002 Malestream geography: gender patterns among UK geography faculty Environment and Planning A 35 1711-1716

Crang P 1992 The politics of polyphony: reconfigurations in geographical authority Environment and Planning D: Society and Space 10 527-549

Crang P 1994 It's showtime: on the workplace geographies of display in a restaurant in southeast England Environment and Planning D: Society and Space 12 675-704

Cresswell T and Merriman P 2011 Geographies of Mobilities: Practices, Spaces, Subjects Ashgate Publishing, Farnham

Crewe L and Gregson N 1998 Tales of the unexpected: exploring car boot sales as marginal spaces of contemporary consumption Transactions of the Institute of British Geographers 23 39-53

Daniels S and Veale L 2014 Imagining coastal change: reflections on making a film cultural geographies 21 497-504

Davies G 2000 Science, observation and entertainment: competing visions of postwar British natural history television, 1946-1967 cultural geographies 7 432-460

DeLyser D 2014 Towards a participatory historical geography: archival interventions, volunteer service, and public outreach in research on early women pilots. Journal of Historical Geography 46 93-98

DeLyser D 1999 Authenticity on the ground: engaging the past in a California ghost town. Annals of the Association of American Geographers 89 602-632

DeSilvey C 2007 Art and archive: memory-work on a Montana homestead Journal of Historical Geography 33 878-900

Domosh M 1991 Toward a feminist historiography of geography. Transactions of the Institute of British Geographers 16 95-104

Driver F 1988 Moral geographies: social science and the urban environment in midnineteenth century England Transactions of the Institute of British Geographers 13 275-287

Driver F 2001 Geography Militant: Cultures of Exploration and Empire Blackwell, Oxford

Driver F 2013.Hidden histories made visible? Reflections on a geographical exhibition. Transactions of the Institute of British Geographers 38 420-435

Endfield G H and Morris C 2012 'Well weather is not a girl thing is it?' Contemporary amateur meteorology, gender relations and the shaping of domestic masculinity Social \& Cultural Geography 13 233-253 
ESRC 2013 International Benchmarking Review of UK Human Geography (http://www.esrc.ac.uk/files/research/evaluation-and-impact/internationalbenchmarking-review-of-uk-human-geography/) Accessed 10 January 2016

Foster K and Lorimer H 2007 Cultural geographies in practice cultural geographies 14 425-432

Fuller D 2008 Public geographies: taking stock Progress in Human Geography 32834-844

Garrett B L 2011 Videographic geographies: using digital video for geographic research. Progress in Human Geography 35 521-541

Garrett B L 2014 Undertaking recreational trespass: urban exploration and infiltration Transactions of the Institute of British Geographers 39 1-13

Geoghegan H 2009 'If you can walk down the street and recognise the difference between cast iron and wrought iron, the world is altogether a better place': being Enthusiastic about Industrial Archaeology M/C Journal 12

Geoghegan H 2010 Museum geography: Exploring museums, collections and museum practice in the UK. Geography Compass 4 1462-1476

Geoghegan H 2013 Emotional geographies of enthusiasm: belonging to the Telecommunications Heritage Group Area 45 40-46

Geoghegan $\mathbf{H}$ and Woodyer T 2014 Cultural geography and enchantment: the affirmative constitution of geographical research Journal of Cultural Geography 3218-229

Ginn F 2014 Sticky lives: slugs, detachment and more-than-human ethics in the garden Transactions of the Institute of British Geographers 39 532-544

Hall S, Hobson D, Lowe A and Willis P eds 1980 Culture, Media, Language: Working Papers in Cultural Studies 1972-79 Hutchinson, London

Hawkins H 2013 For Creative Geographies: Geography, Visual Arts and the Making of Worlds Routledge, London

Hawkins H 2013 Geography and art. An expanding field Site, the body and practice Progress in Human Geography 37 52-71

Head L and Atchison J 2009 Cultural ecology: emerging human-plant geographies Progress in Human Geography 33 236-245

Jackson P 1989 Maps of Meaning: An Introduction to Cultural Geography Routledge, London

Jackson P 2000 Rematerializing social and cultural geography Social \& Cultural Geograpby 19-14

Jackson P and Smith S J eds 1984 Exploring Social Geography George Allen \& Unwin, London 
Jacobs J M 2006 A geography of big things cultural geographies 13 1-27

Kobayashi A 1994 Coloring the field: gender, 'race,' and the politics of fieldwork The Professional Geographer 46 73-80

Kong L 2001 Mapping 'new' geographies of religion: politics and poetics in modernity Progress in human geography 25 211-233

Kraftl P 2010 Geographies of architecture: the multiple lives of buildings Geography Compass 4 402-415

Kraftl P and Adey P 2008 Architecture/affect/inhabitation: geographies of being-in buildings Annals of the Association of American Geographers 98 213-231

Little J 2002 Rural geography: rural gender identity and the performance of masculinity and femininity in the countryside Progress in Human Geography 26 665-670

Lorimer H 2005 Cultural geography: the busyness of being 'more-than-representational' Progress in Human Geography 29 83-94

Maddrell A, Strauss K, Thomas N J and Wyse S 2016 Mind the gap: gender disparities still to be addressed in UK Higher Education geography Area 48 48-56

Martins L 2009 The making of 'landscape surgery' at Royal Holloway cultural geographies, $1621-22$

Massey D 1984 Spatial Divisions of Labour Macmillan, London

Massey D 2013 Doreen Massey on Space

(http://www.socialsciencespace.com/2013/02/podcastdoreen-massey-on-space/)

Accessed 10 January 2016

Mills S 2013 Surprise! Public historical geographies, user engagement and voluntarism Area 45 16-22

Mitchell D 2000 Cultural Geography: A Critical Introduction Blackwell, Oxford

Morin K M 1998 British women travellers and constructions of racial difference across the nineteenth-century American West Transactions of the Institute of British Geographers 23 $311-330$

Nash C 1996 Reclaiming vision: looking at landscape and the body Gender, Place and Culture: A Journal of Feminist Geography 3 149-170

Nash C, Prendergast K and Swenson I 2002 Landings: Eight Collaborative Projects Between Artists and Geographers Royal Holloway, University of London, London

Philo C, Askins, K. and Cook I 2015 Civic geographies: pictures and other things at an exhibition ACME: An International E-Journal for Critical Geographies 14 355-366 
Potter C, Harwood T, Knight J and Tomlinson I 2011 Learning from history, predicting the future: the UK Dutch elm disease outbreak in relation to contemporary tree disease threats. Philosophical Transactions of the Royal Society of London B: Biological Sciences 366 1966-1974

Rogers A 2012 Emotional geographies of method acting in Asian American Theater Annals of the Association of American Geographers 102 423-442

Scalway H 2006 A patois of pattern: pattern, memory and the cosmopolitan city cultural geographies 13 451-457

Shurmer-Smith P 1998 Becoming a memsahib: working with the Indian Administrative Service Environment and Planning A 30 2163-2179

Silk C P and Silk J A 1985 Racism, nationalism and the creation of a regional myth: the southern States after the American Civil War in Burgess J A and Gold J R eds Geography, the Media and Popular Culture Croom Helm, London 165-191

Spinney J 2006 A place of sense: a kinaesthetic ethnography of cyclists on Mont Ventoux Environment and Planning D: Society and Space 24 709-732

Spinney J 2011 A chance to catch a breath: using mobile video ethnography in cycling research Mobilities 6 161-182

Thrift N 2005 From born to made: technology, biology and space Transactions of the Institute of British Geographers 30 463-476

Till K E 2005 The New Berlin: Memory, Politics, Place University of Minnesota Press, Minneapolis

Tolia-Kelly D P 2007 Fear in paradise: the affective registers of the English Lake District landscape re-visited The Senses and Society 2 329-351

Valentine G 1993 (Hetero) sexing space: lesbian perceptions and experiences of everyday spaces Environment and Planning D: Society and Space 11 395-413

Whatmore S 2006 Materialist returns: practising cultural geography in and for a morethan-human world cultural geographies 13 600-609

Whatmore S 2009 Mapping knowledge controversies: science, democracy and the redistribution of expertise. Progress in Human Geograpby 33 587-598

Woodyer T 2008 The body as research tool: embodied practice and children's geographies Children's Geographies 6 349-362

Woodyer T 2012 Ludic geographies: not merely child's play Geography Compass 6 313-326

Woodyer T and Geoghegan H 2013 (Re) enchanting geography? The nature of being critical and the character of critique in human geography Progress in Human Geography 37 195-214 
Wylie J 2010 Cultural geographies of the future, or looking rosy and feeling blue cultural geographies 17 211-217 